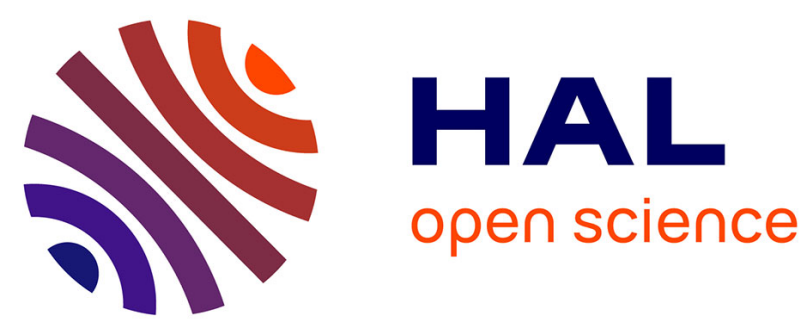

\title{
Reactive Transport Modeling Applied to Ni Laterite Ore Deposits in New Caledonia: Role of Hydrodynamic Factors and Geological Structures in Ni Mineralization
}

Andrey Myagkiy, Fabrice Golfier, Laurent Truche, Michel Cathelineau

\section{- To cite this version:}

Andrey Myagkiy, Fabrice Golfier, Laurent Truche, Michel Cathelineau. Reactive Transport Modeling Applied to Ni Laterite Ore Deposits in New Caledonia: Role of Hydrodynamic Factors and Geological Structures in Ni Mineralization. Geochemistry, Geophysics, Geosystems, 2019, 20 (3), pp.1425-1440. 10.1029/2018GC007606 . hal-02390142

\author{
HAL Id: hal-02390142 \\ https://hal.science/hal-02390142
}

Submitted on 1 Sep 2021

HAL is a multi-disciplinary open access archive for the deposit and dissemination of scientific research documents, whether they are published or not. The documents may come from teaching and research institutions in France or abroad, or from public or private research centers.
L'archive ouverte pluridisciplinaire HAL, est destinée au dépôt et à la diffusion de documents scientifiques de niveau recherche, publiés ou non, émanant des établissements d'enseignement et de recherche français ou étrangers, des laboratoires publics ou privés. 


\section{Geochemistry, Geophysics, Geosystems}

\author{
RESEARCH ARTICLE \\ 10.1029/2018GC007606 \\ Key Points: \\ - New conceptual model of $\mathrm{Ni}$ \\ mineralization is proposed \\ - Two-dimensional coupled \\ hydro-geochemical model for $\mathrm{Ni}$ \\ laterite deposits is developed \\ - Relationship of nickel distribution \\ to fractures and topography is \\ demonstrated
}

Supporting Information:

- Supporting Information S1

- Data Set S1

Correspondence to:

A. Myagkiy,

andrey.myagkiy@univ-grenoble-alpes.fr

Citation:

Myagkiy, A., Golfier, F., Truche, L., \& Cathelineau, M. (2019). Reactive transport modeling applied to $\mathrm{Ni}$

laterite ore deposits in New Caledonia:

Role of hydrodynamic factors

and geological structures in $\mathrm{Ni}$

mineralization. Geochemistry,

Geophysics, Geosystems, 20, 1425-1440.

https://doi.org/10.1029/2018GC007606

Received 11 APR 2018

Accepted 12 FEB 2019

Accepted article online 19 FEB 2019

Published online 15 MAR 2019

\section{Reactive Transport Modeling Applied to Ni Laterite Ore Deposits in New Caledonia: Role of Hydrodynamic Factors and Geological Structures in Ni Mineralization}

\author{
Andrey Myagkiy ${ }^{1} \mathbb{D}$, Fabrice Golfier ${ }^{1} \mathbb{D}$, Laurent Truche ${ }^{2}$, and Michel Cathelineau ${ }^{1} \mathbb{D}$ \\ ${ }^{1}$ Université de Lorraine, CNRS, GeoRessources, Nancy, France, ${ }^{2}$ ISTerre, UMR 5275 of CNRS, University of Grenoble \\ Alpes, Grenoble, France
}

\begin{abstract}
This study is devoted to understanding the impact of topography and hydrodynamics on the formation of high-grade supergene nickel deposits. The investigation proposes a new conceptual mineralization model that describes the formation of various exceptionally Ni-enriched hot spots observed in lateritic profiles. Numerical analysis of the effects of local hydrodynamics on deposits formation is performed by means of PHREEQC geochemical simulator and COMSOL Multiphysics software. These are coupled through an iCP Java interface that allows to code their level of interaction and facilitates the exchange of parameters. The model developed extends the currently existing geochemical formulation of nickeliferous laterite formation from peridotite carried out in 1-D and is additionally capable of simulating mass solute transport and geochemical processes within complex fractured-porous systems. The simulations improve our understanding of metal enrichment in saprolite and bedrock zones. It was shown that, although the initial development of nickel lateritic ores takes a few million years, they are prone to relatively quick leaching and subsequent redistribution of $\mathrm{Ni}$ when the topography changes in response to tectonic processes. The latter leads to the formation of rich nickel deposits at the bottom of the slope, mostly due to leaching of the saprolite material. In addition to the role of changes in topography, the critical impact of fractures and fracture networks on metal mobility and distribution was identified. The model developed provides significant insight into the distribution of mineral resources, in particular Ni deposits, and can be of great help for future mineral prospecting in industry.
\end{abstract}

\section{Introduction}

Formation of Ni laterite deposits from ultramafic bedrock is a complex geological process involving the interplay of tectonics, climate, hydrodynamics, and geochemical reactions (Butt \& Cluzel, 2013; Golightly, 1981, 2010; Trescases, 1975). Indeed, the full complexity of chemical and physical phenomena is acting together over millions of years to shape these composite systems and drive the exceptional Ni enrichment observed locally along the soil profiles nowadays. Hydrolysis and redox reactions are responsible for the destruction of the primary rock-forming minerals and the formation of the secondary minerals in the regolith. After being released, the elements (e.g., $\mathrm{Fe}, \mathrm{Mg}, \mathrm{Ni}$, and $\mathrm{Si}$ ) are leached from the surface and later may be (i) precipitated in secondary minerals, (ii) held within the mineral crystal lattice, (iii) adsorbed at the surface of minerals, and (iv) dissolved in solution, either solvated by the water molecules or "complexed" (Thornber, 1992). Depending on the physicochemical conditions, the superposition of these possible fates of nickel will define the Ni mineralization.

With its intermediate behavior, being more mobile than iron and less than magnesium, Ni is often found to be concentrated at the base of the lateritic profile and in the saprolite horizon, where it attains economic concentrations (over $1 \mathrm{wt} \%$ of $\mathrm{Ni}$ ). In New Caledonia, a typical lateritic profile begins at the top with the laterite zone (Figure 1), which is mainly composed of iron oxyhydroxides (hematite and goethite). This horizon is further replaced by the saprolitic zone that represents an intermediate state of the parent-rock alteration and hosts the most concentrated Ni ores.
(C)2019. American Geophysical Union. All Rights Reserved. 


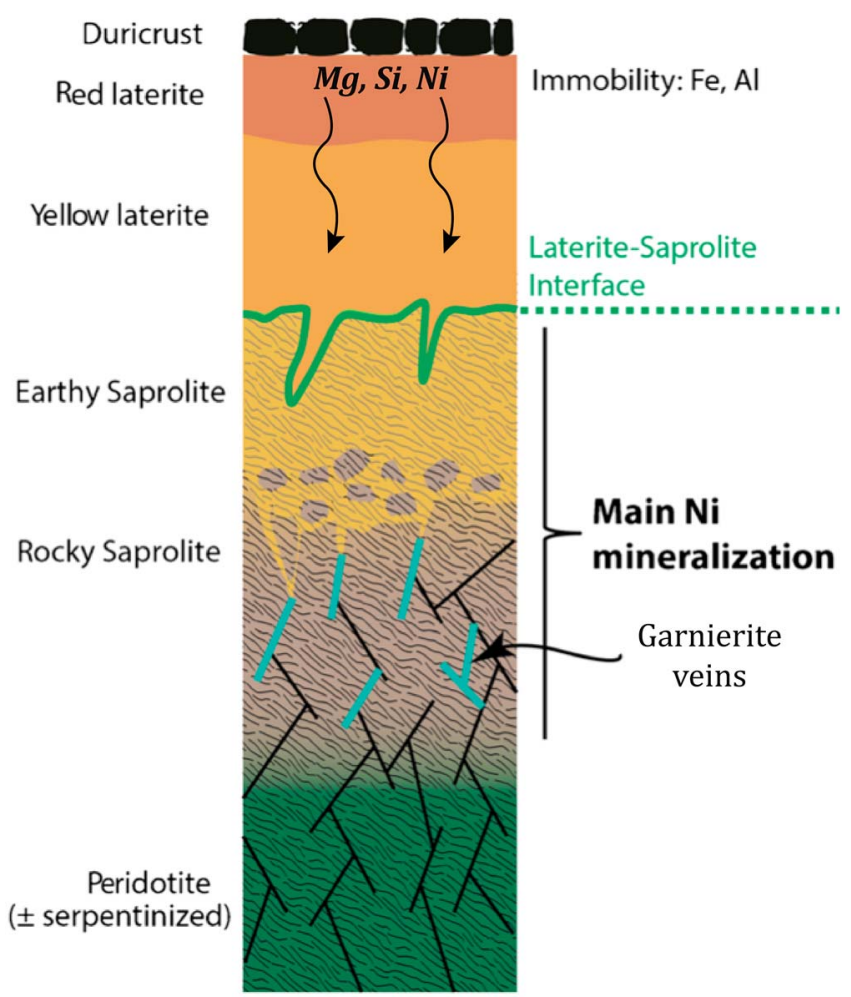

Figure 1. Typical laterite profile of New Caledonia with different zones developed on ultramafic rocks due to the weathering processes. (Modified from Pelletier, 2003; Ulrich, 2010).
A currently existing principal genetic model for Ni ores in New Caledonia is based on a classical per descensum fluid transfer process where most elements (Mg, Ni, and $\mathrm{Si}$ ) are leached from the surface (Pelletier, 1996; Trescases, 1975; Troly et al., 1979). Transport of Ni is regarded as a chemically controlled gradual redeposition along the vertical flowline under the propagation of acidic meteoric water. Nevertheless, a thorough structural and mineralogical investigation over the last decades revealed a complex influence of fracture networks, geomorphological development, and topography on ore distribution (Chevillotte et al., 2006; Cluzel \& Vigier, 2008; Leguere, 1976; Quesnel et al., 2017; Villanova-de-Benavent et al., 2014). Some authors propose that neogenic tectonic activity facilitated supergene alteration by promoting meteoric water circulation and contributed to a local redistribution of nickel in the saprolitic level (Cluzel \& Vigier, 2008). Geometrical modeling of the lateritic cover at Koniambo (west side of New Caledonia), correlated with the metal content in drill cores, suggests an important influence of relief on laterite thickness (Quesnel et al., 2017). In addition, the presence of local heterogeneities in Ni enrichment within the profiles, namely, (i) concentric zonation of Ni silicates (Cathelineau, Quesnel, et al., 2016) and (ii) garnierite veins, as well as (iii) geological observations demonstrating that most of the $\mathrm{Ni}$-rich areas are often not spatially associated to the thickest lateritic body, all together lead to the conclusion that formation of the Ni laterite ore deposit has to be regarded as at least a 2-D process and current per descensum model and, thus, should be revised.

To date, only two research papers have been published on reactive transport modeling of the development of a nickeliferous laterites from peridotite. The first attempts of making such a model for ultramafic environment were performed by Domènech et al. (2017) and Myagkiy et al. (2017) highlighting the main chemical retardation processes for $\mathrm{Ni}$ and reproducing in situ observations of Ni enrichment in vertical lateritic profiles. Providing a detailed understanding of trace elements mobility and weathering process along with powerful chemical basis, these models, nonetheless, have a weak point in their 1-D hydrodynamic part. Therefore, the idea of coupling the state of the art of the geochemical model with relevant hydrodynamics became an objective of this work. Yet a few coupled geochemical and fluid flow models have been developed to study hydrodynamic impact on locations of deposits in some mineral-rich terrains in the world. Some examples concern the formation of gold (Zhang et al., 2008), uranium (Aghbelagh \& Yang, 2017), and $\mathrm{Pb} / \mathrm{Zn}$ deposits (Hobbs et al., 2000) and do not concern ultramafic environments. The models are generally studying simple hydrodynamics and restricted by one chemical domain.

Here we test a new concept of ore genesis to explain metal enrichment in saprolite and bedrock by taking into account preferential pathways (i.e., fractures), lateral transfers, and topographic influence during the supergene alteration processes. The main objective of this paper is to provide an explanation for the local mineralizing distributions of nickel and understand their driving forces. Therefore, 2-D reactive transport simulations were conducted to assess these aspects based on a coupling approach between geochemistry, hydrodynamics, and mass transfer. We present investigations of local hydrodynamics control on ore development with particular emphases on (i) the conceptual model of laterite formation based on migration of $\mathrm{pH}$ dissolution front within the ultramafic uplifted environment, (ii) nickel remobilization and subsequent redistribution in a profile, and (iii) impact of topography and fractures on local mineralizing distributions.

\section{Materials and Methods}

2.1. Conceptual Model of Saprolitic Nickel-Ore Formation in New Caledonia

Formation of mineral deposits often results from interaction between several key processes including structural (faults, fractures, and topographic changes), hydrological (fluid flow), thermal (geothermal transport), and geochemical (e.g., mineral dissolution and precipitation, adsorption, and substitution in the crystal lattice) impacts. Lateritic Ni ore deposits in New Caledonia are not an exception. Here the stepped-land surfaces 


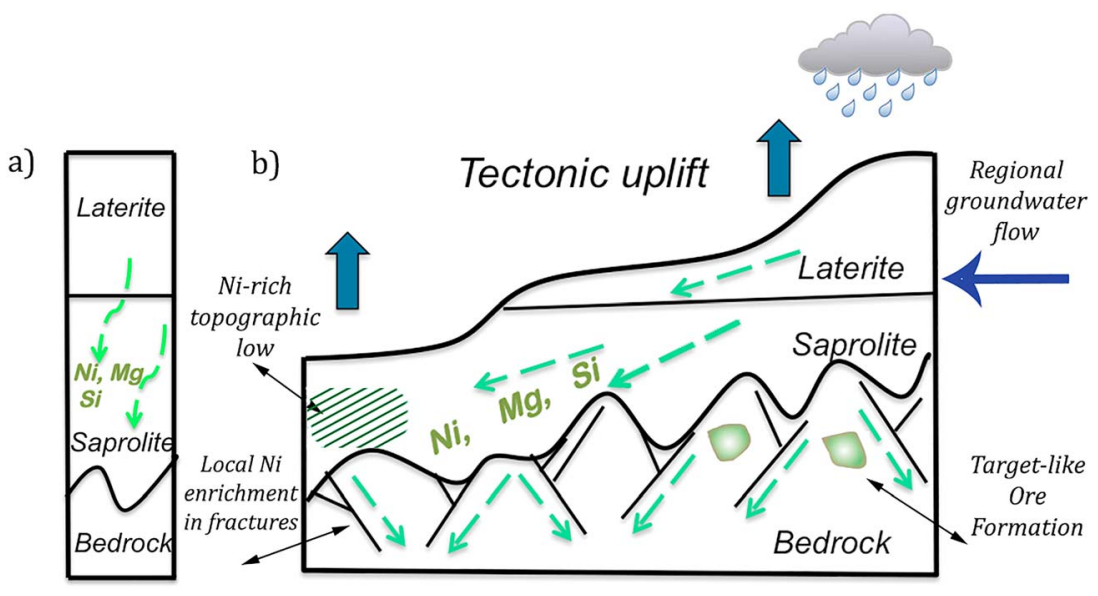

Figure 2. (a) Present-day unidimensional concept of redistribution of Ni deposits in uplifted profile according to Butt and Cluzel (2013), and (b) proposed conceptual 2-D model with formation of different Ni mineralization hot spots after tectonic uplift of regolith.

suggest that the weathering of laterites originally started on a landscape of low to moderate relief (Lower Oligocene, 33.9 to $28.1 \mathrm{Ma}$ ) and further continued as these surfaces were uplifted (e.g., Chevillotte et al., 2006; Sevin et al., 2012). A unidimensional concept of evolution of Ni deposits with their subsequent uplift and redeposition was proposed in a work of Butt and Cluzel (2013). The model implies remobilization of Ni from the oxide zone (laterite) of uplifted formation due to redissolution of Ni-bearing goethite and its subsequent accumulation in hydrous Mg-Ni silicates deeper in the saprolite (Figure 2a). Nevertheless, none of the present-day $\mathrm{Ni}$ ore genesis concepts takes into account the hydrodynamic control on Ni remobilization that constitutes an important part of mineralization model.

Here we propose a renewed examination of the per descensum migration model based on a hydrodynamic study at a deposit scale with the purpose of demonstrating the structural controls associated with the location of nickel-bearing deposits. In coherence with Butt and Cluzel (2013) we assume the development of lateritic and saprolitic horizons began on a flat relief with subsequent downward leaching of the components. Then, in some stage of formation, regolith underwent the tectonic uplift that has led to rejuvenation of the topography, formation of new sets of fractures, and, thus, change of hydraulic gradients. This latter process has modified the behavior of the fluid flow and consequently the direction of chemical solution drainage. As a result, the weathering of this complex system led to the formation of different locally observed $\mathrm{Ni}$ enrichments. This way, the classical per descensum model was extended (Figure $2 \mathrm{~b}$ ) by integrating lateral variation due to topographic effects, and the presence of preferential pathways, in order to address the formation of local Ni mineralizations.

The mechanism accounting for the formation of the Ni-enriched hot spots is proposed to be the following. The migration of meteoric fluid along the slope triggered the lateral transfer of mineral constituents, namely, $\mathrm{Ni}, \mathrm{Si}$, and $\mathrm{Mg}$, from the upper horizons. These successive dissolution-precipitation cycles driven by movement of $\mathrm{pH}$ front eventually led to redeposition of Ni-bearing minerals in the direction of the flow and to an increase of Ni grade in the saprolite, especially downstream of ridges and in low-relief zones. In addition, the presence of preferential pathways within the bedrock resulted in partial migration of the fluid into these highly permeable sites. Subsequent oversaturation of the solution with respect to pimelite within the fractures contributed to the formation of high-grade Ni silicate ore. Another type of local Ni mineralization, also closely associated with fractures network, was formed in joints within the peridotite blocks occurring within the first hundred meters below the surface. This so-called target-like ore (Cathelineau, Quesnel, et al., 2016) represents a concentric zonation of a pimelite and kerolite with the extension ranges from a few decimeters to $1 \mathrm{~m}$. The formation of this ore is closely tied to the fluid penetration and subsequent chemical alteration of the individual blocks within the regular fractures network. 
The present mineralization model highlights critical control of geological structures on Ni ore development. In the following, we will pay specific attention to understanding the above discussed local Ni-enriched hot spots, namely, (i) topographically controlled increase of Ni grade in the zone of low relief, (ii) precipitation of Ni-bearing pimelite within the fractures, and (iii) formation of concentric Ni-silicate ore under the control of fracture networks. This numerical investigation will be performed through three separate multicomponent reactive transport models accompanied by the appropriate hydrodynamic system. The models include the analyses of (i) the lateral propagation of the dissolution front under the influence of a topographic gradient, (ii) the impact of fractures on the fluid hydrodynamics along the profile and the subsequent remobilization of nickel, and (iii) the effect of fracture network on weathering and successive dissolution-precipitation cycles within the boulders. The results obtained provide detailed understanding of metal enrichment in saprolite and bedrock and further support the presented concept of $\mathrm{Ni}$ ore genesis.

\subsection{Physical Assumptions and Equations Governing Hydrodynamic System}

Due to the complicated nature of an ore-forming process, it is very tough to simultaneously simulate the entire mineralizing system and the model thus includes several assumptions listed below. First of all, we neglect any mechanical or tectonic deformations that may occur during a mineralization event. Since the timescale of synmineralization mechanical deformation is way shorter than that of deposit formation, we assume that the synmineralization mechanical deformation divides the mineralizing system into two episodes and separately simulate the cases without and with fractures. Assuming a typical intracontinental geothermal gradient of $30{ }^{\circ} \mathrm{C} / \mathrm{km}$ (Fridleifsson et al., 2008) and the formation of deposits generally within the first hundred meters below the surface, we neglect the temperature changes as its influence on thermodynamic constants will be minor.

As long as the conceptual model is focused on redistribution of Ni minerals within the profile that happened on a timescale after the tectonic uplift of weathered laterite, the system should have already undergone the main mass losses of up to $80 \%$ due to the downward leaching of $\mathrm{Ni}, \mathrm{Si}$, and $\mathrm{Mg}$. Together with short modeling time of up to 500 years, it leads to negligible possible changes in porosity and permeability within the profile. Thus, porosity and permeability changes over the timescale of the simulations are not taken into account. We consider the water table to be close to the ground surface and limit our analysis to the fully saturated region. The latter is justified in case of the wet rain forest settings such as New Caledonia, where pore space is nearly saturated with water, even above the water table (Golightly, 2010). Finally, we assume the fluid phase as an ideal mixing of highly diluted solutes so that liquid density and viscosity variations can be ignored.

A coupled model considers the concentrations of several aqueous species and is able to simulate both solute transport processes, namely, advection and dispersion, and chemical reactions, such as dissolution, precipitation, complexation, and adsorption. Equations that govern the hydrodynamic system are represented by the conservative solute transport equation that describes the time rate of change of solute concentration for a single solute, continuity equation and Darcy flow equation:

In liquid phase,

$$
\frac{\partial\left(\phi c_{l}\right)}{\partial t}+\nabla \cdot\left(\mathbf{u} c_{l}\right)=\nabla \cdot\left(\phi \mathbf{D}_{1} \nabla c_{l}\right)+R_{l}^{*}
$$

In solid phase,

$$
\frac{\partial\left((1-\phi) c_{s}\right)}{\partial t}=R_{s}^{*}
$$

Continuity equation,

$$
\nabla \cdot \mathbf{u}=0
$$

where $c_{l}$ and $c_{s}$ are concentrations of chemical species per volume of fluid and solid, respectively $\left(\mathrm{mol} / \mathrm{m}^{3}\right)$, $\mathbf{u}$ is the Darcy velocity $(\mathrm{m} / \mathrm{s}), \mathbf{D}_{l}$ is the local diffusion/dispersion tensor $\left(\mathrm{m}^{2} / \mathrm{s}\right), \phi$ is the porosity $\left(\mathrm{m}^{3} / \mathrm{m}^{3}\right)$.

Darcy flow is defined as follows:

$$
\mathbf{u}=-\frac{\mathbf{k}}{\mu} \cdot(\nabla \mathrm{p}-\rho \mathbf{g}),
$$


Table 1

Physical Parameters Applied in Simulations

\begin{tabular}{lcc}
\hline Parameter & Symbol & Value \\
\hline Dynamic viscosity & $\mu$ & $10^{-3} \mathrm{~Pa} \cdot \mathrm{s}$ \\
Temperature & $\mathrm{T}$ & $25^{\circ} \mathrm{C}$ \\
Density & $\rho$ & $10^{3} \mathrm{~kg} / \mathrm{m}^{3}$ \\
Porosity: saprolite, laterite & $\phi_{1}$ & 0.4 \\
Porosity: bedrock & $\phi_{2}$ & 0.1 \\
Porosity: fracture & $\phi_{3}$ & 1 \\
Permeability: saprolite, laterite & $k_{1}$ & $10^{-13} \mathrm{~m}^{2}$ \\
Permeability: bedrock & $k_{2}$ & $10^{-15} \mathrm{~m}^{2}$ \\
Permeability: fracture & $k_{3}$ & $10^{-5} \mathrm{~m}^{2}$ \\
Constant injection rate & $Q_{0}$ & $6.3 \times 10^{-8} \mathrm{~m} / \mathrm{s}$ \\
Hydraulic head: upslope & $H_{1}$ & $70 \mathrm{~m}$ \\
Hydraulic head: downslope & $H_{2}$ & $20 \mathrm{~m}$ \\
Length & $L$ & $140 \mathrm{~m}$ \\
Pressure: fracture & $P$ & $3 \times 10^{5} \mathrm{~Pa}$ \\
\hline
\end{tabular}

where $\mathbf{k}$ stands for the intrinsic permeability tensor of the medium $\left(\mathrm{m}^{2}\right), \mu$ denotes the dynamic viscosity $(\mathrm{Pa} \cdot \mathrm{s}), \mathrm{p}$ refers to the liquid pressure $(\mathrm{Pa}), \rho$ is the liquid density $\left(\mathrm{kg} / \mathrm{m}^{-3}\right)$, and $\mathbf{g}$ is the acceleration of gravity $\left(\mathrm{m}^{2} / \mathrm{s}^{2}\right)$.

Note that the reaction terms $R^{*}$ in equations (1) and (2) take into account concentration changes due to surface complexation mechanism, equilibrium reactions, and kinetic dissolution of primary rock (see details in section 2.3).

The studied hydrodynamic system reproduces typical laterite profile after the formation was uplifted. Four zones with different hydrodynamic parameters are explicitly defined in the simulation, namely, laterite, saprolite, bedrock, and fracture (Figure 2). In New Caledonia, permeability values in the saprolite and laterite layers are high. The present-day permeability values for the coarse saprolite of New Caledonia have been estimated at around $10^{-13} \mathrm{~m}^{2}$ (Join et al., 2005). Apparent intrinsic permeability of the ultramafic fractured bedrock was chosen to be about $10^{-15} \mathrm{~m}^{2}$ but is highly dependent on the fractures density (Jeanpert \& Dewandel, 2013; Join et al., 2005). Centimeter-thick fractures presented within the bedrock of New Caledonian profiles were assumed to have the permeability of $10^{-5} \mathrm{~m}^{2}$ in accordance with the cubic law, implying that transmissivity is proportional to cube of the aperture. Further, the local dispersion tensor is assumed to be constant and homogeneous. It will be fixed to $4 \times 10^{-7}\left(\mathrm{~m}^{2} / \mathrm{s}\right)$. The main physical parameters used in the model are listed in Table 1.

Incoming solution that reproduces the atmospheric precipitation (rainwater) was introduced at the geometrical top and along the slope of each modeling case as a constant recharge rate boundary. It has a chemical composition of a slightly acidic tropical rainwater with $\mathrm{pH}=5.6$ due to its equilibrium with atmospheric $\mathrm{CO}_{2}$ (see Myagkiy et al., 2017, Figure 3). For our simulations the value of 2,000 mm/year of the rainfall was chosen as acceptable in accordance with Butt and Cluzel (2013). The boundary conditions imposed on the left and right parts of the simulated domain were hydraulic heads with the corresponding values of topographic dimensions. Solution, entering the system from the right boundary in a case of sloped uplifted regolith, is represented in simulations by the same chemical composition as rainwater. Natural recharge of this regional groundwater flow is assumed to be at the topographic top of the simulated domain, so the modifications of rainwater $\mathrm{pH}$ can be considered as minor. The bottom of the bedrock is represented by the flux insulation condition, unless the modeling case where the fracture is introduced. In the latter situation, a pressure condition is imposed at the end of the crack. Natural outflow of the fractured system is assumed to occur a few hundred meters below the ground surface.

\subsection{Geochemical System}

The geochemical system reproduces typical laterite profile after the formation was uplifted (Figure 2). The first simulated profile is represented by three different chemical horizons with corresponding mineralogical composition of laterite, saprolite, and bedrock. The composition is taken in accordance with the results of

Table 2

Mineral Composition of Modeled Horizons

\begin{tabular}{llc}
\hline Zone & Mineral & Molar fraction \\
\hline Laterite & Goethite_Ni & 1 \\
Saprolite & Olivine & 0.184 \\
& Kerolite & 0.389 \\
& Pimelite & 0.146 \\
& Goethite & 0.281 \\
Bedrock & Olivine & 1 \\
\hline
\end{tabular}

1-D model (Myagkiy et al., 2017) after $10 \mathrm{Ma}$ of laterite development and minerals are homogeneously spread within each horizon. Distribution of the minerals in the chemical domains is the following: (a) lateritic zone is infilled with Ni-bearing goethite; (b) saprolitic horizon, representing an intermediate step in ultramafic rock alteration, is composed of Ni-rich silicates presented by talk-like phases, goethite, and partially preserved olivine; and (c) the bedrock is fully composed of fresh peridotite (olivine). Irregular boundaries between the saprolite and bedrock layers are schematically represented in accordance with in situ observations within the quarries of New Caledonia and caused by the initial sets of fractures in the early stages of the ophiolite weathering (Figure 2). Molar fractions of minerals presented in each chemical domain are listed in Table 2. 
Table 3

Dissolution Reactions for Precipitating Minerals With the Corresponding Equilibrium Constants at $25^{\circ} \mathrm{C}$

\begin{tabular}{|c|c|c|}
\hline Mineral & Reaction & $\log \mathrm{K}$ \\
\hline Kerolite & $\mathrm{Mg}_{3} \mathrm{Si}_{4} \mathrm{O}_{10}(\mathrm{OH})_{2}: \mathrm{H}_{2} \mathrm{O}+6 \mathrm{H}^{+}=3 \mathrm{Mg}^{2+}+4 \mathrm{SiO}_{2(\mathrm{aq})}+5 \mathrm{H}_{2} \mathrm{O}$ & 25.79 (Stoessell, 1988) \\
\hline Pimelite & $\mathrm{Ni}_{3} \mathrm{Si}_{4} \mathrm{O}_{10}(\mathrm{OH})_{2}: \mathrm{H}_{2} \mathrm{O}+6 \mathrm{H}^{+}=3 \mathrm{Ni}^{2+}+4 \mathrm{SiO}_{2(\mathrm{aq})}+5 \mathrm{H}_{2} \mathrm{O}$ & 11.46 (Nriagu, 1975) \\
\hline Sepiolite & $\mathrm{Mg}_{4} \mathrm{Si}_{6} \mathrm{O}_{15}(\mathrm{OH})_{2}: 6 \mathrm{H}_{2} \mathrm{O}+8 H^{+}=4 \mathrm{Mg}^{2+}+6 \mathrm{SiO}_{2(\mathrm{aq})}+11 \mathrm{H}_{2} \mathrm{O}$ & 30.44 (Stoessell, 1988) \\
\hline Falcondoite & $\mathrm{Ni}_{4} \mathrm{Si}_{6} \mathrm{O}_{15}(\mathrm{OH})_{2}: 6 \mathrm{H}_{2} \mathrm{O}+8 \mathrm{H}^{+}=4 \mathrm{Ni}^{2+}+6 \mathrm{SiO}_{2(\mathrm{aq})}+11 \mathrm{H}_{2} \mathrm{O}$ & 12.31 (Nriagu, 1975) \\
\hline Saponite-Mg & $\mathrm{Mg}_{3.16} \mathrm{Al}_{0.33} \mathrm{Si}_{3.67} \mathrm{O}_{10}(\mathrm{OH})_{2}+7.32 \mathrm{H}^{+}=3.16 \mathrm{Mg}^{2+}+0.33 \mathrm{Al}^{3+}+3.67 \mathrm{SiO}_{2}+4.66 \mathrm{H}_{2} \mathrm{O}$ & 26.25 (llnl.dat) \\
\hline Goethite_Ni & $\mathrm{Fe}_{0.98} \mathrm{Ni}_{0.03} \mathrm{OOH}+3 \mathrm{H}^{+}=0.98 \mathrm{Fe}^{3+}+0.03 \mathrm{Ni}^{2+}+2 \mathrm{H}_{2} \mathrm{O}$ & 0.53 (llnl.dat) \\
\hline Quartz & $\mathrm{SiO}_{2}=\mathrm{SiO}_{2(\mathrm{aq})}$ & -3.99 (llnl.dat) \\
\hline
\end{tabular}

Complementary simulations introduce the presence of fractures in the bedrock. The fractures are modeled as 2-D objects of 3.5-cm width which, thus, lead to some limitation on their presented number in a model regarding the computational cost. First we simulate the impact of one fracture of $18 \mathrm{~m}$ long within the peridotite on redistribution of $\mathrm{Ni}$ ore deposits in saprolite zone. Second, we introduce four fractures $(3.5 \mathrm{~cm}$ in width and $1.8 \mathrm{~m}$ in length) in a peridotite system that is reproducing the corestones alteration in a regular fractures network within the bedrock horizon.

These latter simulations also have an additional chemical domain that is being computed within the fracture. In initial state all the fractures are assumed to be void. The precipitation-dissolution processes are activated in every model subdomain, namely, laterite, saprolite, bedrock, and fracture, and considered to occur according to local equilibrium. Olivine composition in the model was selected according to Trescases (1975) as follows: $\mathrm{Mg}_{1.82} \mathrm{Fe}_{0.17} \mathrm{Ni}_{0.01} \mathrm{Al}_{0.006} \mathrm{SiO}_{4}$ and assumed to be kinetically controlled during the simulation. Specific dissolution rate for olivine was simulated in accordance with research papers of Pokrovsky and Schott (2000) and Prigiobbe et al. (2009):

$$
\log (r)=-0.5 \mathrm{pH}-6.64 .
$$

The overall olivine reaction rate in the model was defined as follows:

$$
R=r\left(\frac{A_{0}}{V}\right)\left(\frac{m}{m_{0}}\right)^{n},
$$

where $R$ signifies the overall reaction rate $(\mathrm{mol} / \mathrm{L} / \mathrm{s}), r$ is the specific dissolution rate $\left(\mathrm{mol} / \mathrm{m}^{2} / \mathrm{s}\right)$ extracted from equation (5), $A_{0}$ refers to the initial surface area of the solid $\left(\mathrm{m}^{2}\right), V$ designates the volume of solution $(l), m_{0}$ represents the initial moles of solid, and $m$ is the moles of solid at a given time. For a monodisperse population of uniformly dissolving spheres or cubes, $n=2 / 3$, since $m$ is proportional to the volume, or $\tilde{r}^{3}$ (here $\tilde{r}$ is the radius of the sphere or the side of the cube), while the surface area is proportional to $\tilde{r}^{2}$. The initial surface area of olivine was set to be $9.41 \mathrm{~m}^{2} / \mathrm{kg}$.

Thermodynamic database for surface complexation of inorganic ions on goethite developed by Dzombak and Morel (1990) was used in simulations. The surface complexation model was kept active in both laterite and saprolite horizons where goethite is present since it was proved that adsorption has an important impact on $\mathrm{Ni}$ and Mg mobility (Myagkiy et al., 2017). Chemical calculations were performed at $25^{\circ} \mathrm{C}$ within the code PHREEQC (Parkhurst \& Appelo, 2013) associated with the llnl.dat thermodynamic database (Johnson et al., 2000), that has been edited in order to account for garnierite minerals. The reactions involved in simulations along with minerals allowed for precipitation-dissolution are listed in Table 3.

\section{Numerical Model and Validation}

The coupling between fluid flow and geochemistry was performed using iCP (interface COMSOL-PHREEQC) platform for solving THC (thermo-hydro-chemical) problems (Nardi et al., 2014). It unites the capabilities of both geochemical code PHREEQC (Parkhurst \& Appelo, 2013) and the multiphysics software COMSOL Multiphysics v.5.1. The parallelization of chemical reactions is achieved by grouping sets of nodes which are then solved on different threads. The reactive transport equations are solved with a sequential noniterative approach that consists of separately solving the chemical equations and the transport equations (see, e.g., Saaltink et al., 2001). The conservative multicomponent transport is, 


\section{Constant recharge, incoming chemical solution}

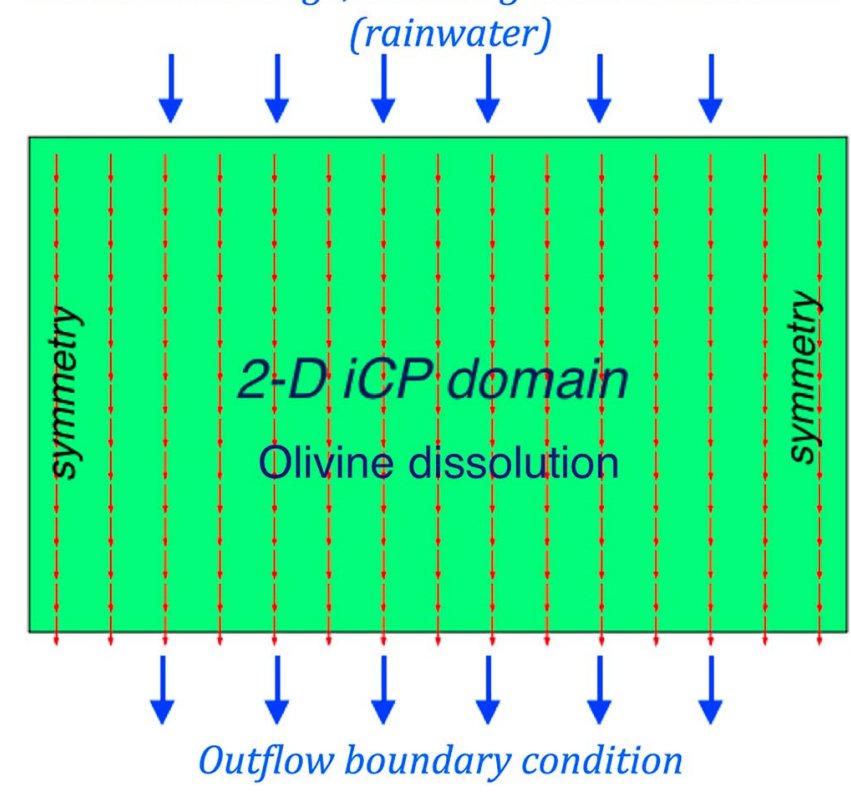

Figure 3. Simplified model used for validation of iCP results. The dimensions are $20 \times 30 \mathrm{~m}$. iCP $=$ interface COMSOL-PHREEQC. thus, computed in the first step with COMSOL. Reactive chemistry is evaluated by PHREEQC in a second step. In comparison with an existing iterative scheme, the used noniterative approach does not pose global convergence problems. Nevertheless, it requires a strong control of the time step connecting geochemical and hydrodynamic parts of calculation in order to avoid huge operator-splitting errors (e.g., Barry et al., 1996; Carrayrou et al., 2004; Jacques et al., 2006).

In this way, the correctness of the implementation was assessed by solving a benchmark scenario using iCP. This validation part was performed on a rectangular 2-D domain with symmetry conditions on both sides in order to obtain 1-D perpendicular flowlines (Figure 3). The results of iCP have been compared to the same length column of 1-D reactive transport model calculated with PHREEQC code alone, which in that case was used to solve both transport and geochemical reactions. Observation point was chosen to be at the last cell of 1-D flowline and at the lower boundary in PHREEQC and iCP, respectively. The boundary conditions, mineral composition of the domain, and the list of reactions were reproduced from the geochemical conceptual model of peridotite weathering from Myagkiy et al. (2017), on a reduced timescale which was set as $10^{8}$ $\mathrm{s}$ (3 years). Thereby, the chemical models and transport pathways were identical in both iCP and PHREEQC simulations.

As the COMSOL Multiphysics is based on the finite element method the concentrations were, therefore, calculated at the nodes. Each node concentration is further passed through the iCP interface to PHREEQC at every communication time step in order to perform the chemical calculations. The validation of the algorithm prior to launching the modeling exercise proved to be of critical importance in coupled simulations with iCP. Indeed, the use of a sequential noniterative approach in combining of PHREEQC and COMSOL Multiphysics appeared to be sensitive to the size of communication time steps and required particular attention.

Correct result was achieved with the size of the communication time steps of data exchange between physics (i.e., COMSOL calculations) and chemistry (i.e., PHREEQC calculations), equal to $10^{6} \mathrm{~s}$. Infiltration of water into the system led to the weathering of initially presented primary rock (olivine) to the secondary minerals: goethite, pimelite, kerolite, and saponite. The evolution of paragenesis at the outlet of the column over the studied time domain of $10^{8} \mathrm{~s}$ can be seen in Figure 4. The results computed with iCP were proved to closely match the solution obtained by using PHREEQC. Further presented simulations were then performed conserving the verified communication step. In the following, three different $\mathrm{Ni}$ mineralization hot spots, presented in section 2.1, will be investigated.

\section{Results and Discussion}

\subsection{Two-Dimensional Reactive Transport Model of Saprolitic Deposits Formation}

Most of the lateritic nickel deposits in New Caledonia as well as in other parts of the world provide classic examples of topographic control on laterite and saprolite development (see, e.g., Golightly, 1979; Latham, 1986; Murphy et al., 2004). The topography of the ultramafic massifs in the southern (Massif Sud) and western part (Koniambo massif) of the main island, Grande Terre, results from the progressive uplift and dismantling of a Tertiary plain (Trescases, 1975). The uplift may attain a few tens or even several hundred meters of elevation, and terrane often forms V-shaped mountain valleys with slopes of higher than $20^{\circ}$. The thickest nickel lateritic zones are usually preserved on fragments of the uplifted and dismantled peneplain, generally located on topographic
Figure 4. Comparison of the results with $\mathrm{iCP}$ and PHREEQC observed at the last cell of the column for the 1-D verification case. $\mathrm{iCP}=$ interface COMSOL-PHREEQC. 

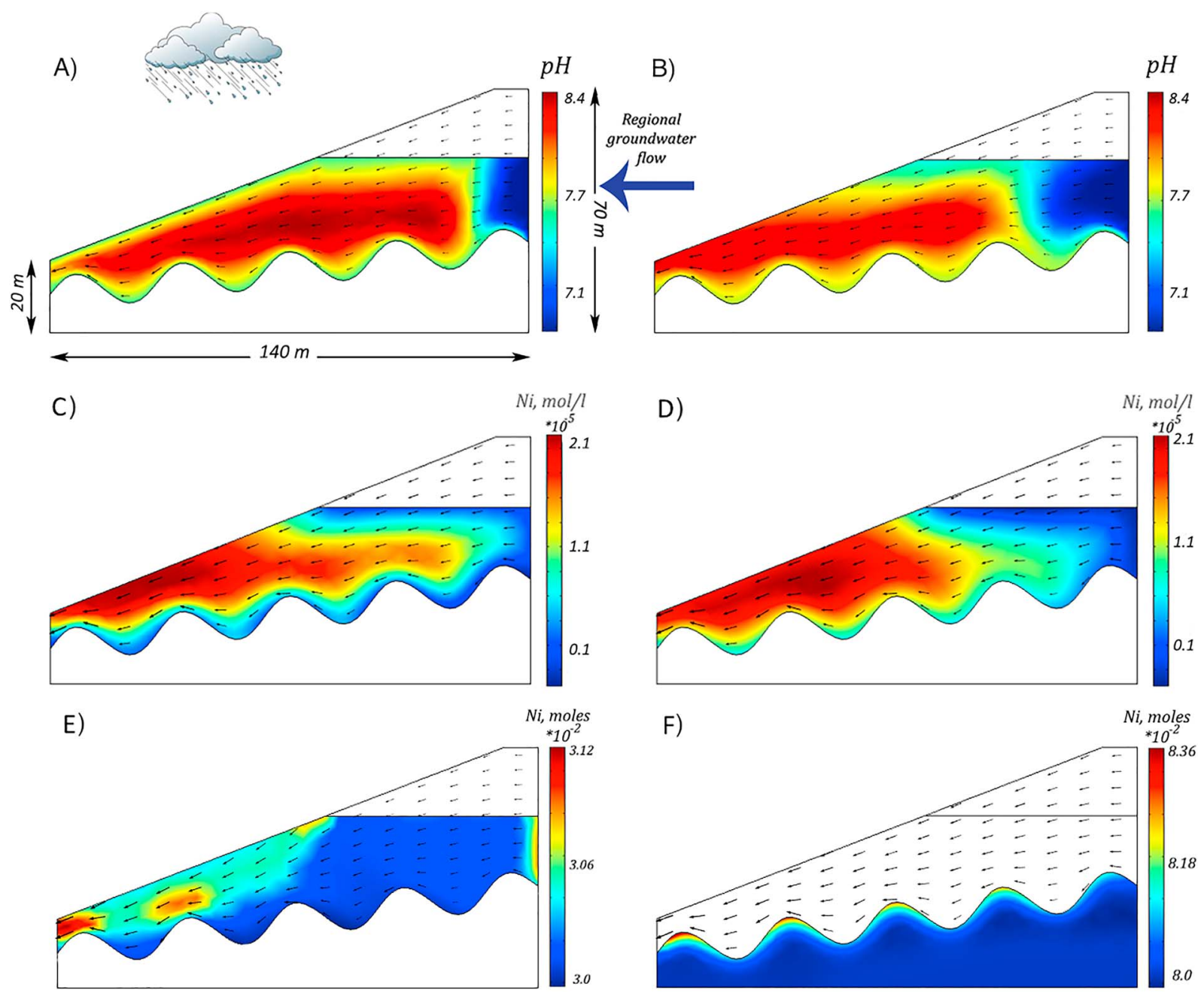

Figure 5. Propagation of $\mathrm{pH}$ front in saprolitic layer after (a) 50 years and (b) 100 years. Total Ni aqueous concentration (c) 50 years and (d) 100 years. Distribution of total Ni content (in moles) within the (e) saprolitic and (f) bedrock horizons after 500 years. The incoming solution penetrates from the geometrical top of the domain and on a slope, as well as from the right lateral boundary due the regional groundwater flow. The discharge zone is introduced on the left boundary, in the zone of low relief. The arrows stand for flow vectors.

highs (Golightly, 2010). In opposite, thin and incomplete laterite profiles were found on low slopes and at their base (Quesnel et al., 2017). In order to reveal the impact of topographic gradients on the formation of laterite and distribution of saprolitic ore deposits, let us turn to the results of numerical modeling.

Physical dimensions of investigated regolith are introduced in Figure 5a. The inclination of the slope in the simulation case was $22^{\circ}$. At first approximation, the impact of heterogeneities (fractures) within the bedrock is neglected, so the fluid flow in the lower layer (bedrock) is very slow compared to the upper saprolite horizon. Due to the factthat geological horizons have different permeabilities (Table 1) and initial mineral compositions (Table 2), they differ considerably in values of concentration changes in time. As it impacts the visual scale, we permanently highlight the results of concentration in only one separate zone (e.g., Figure 5). Having said that, it is important to note that the simulations take place in all the geological layers for each modeling case presented in this paper.

The numerical problem has been solved with parallel direct sparse solver (PARDISO), with relative and absolute tolerance of 0.01 and 0.001 respectively in this and following simulation cases. For the current case, where fractures are absent, the size of simulation domains involved in calculation is composed of 678 nodes, which conducts correct convergence of the simulations.

Figures $5 \mathrm{a}$ and $5 \mathrm{~b}$ show the evolution of the $\mathrm{pH}$ front, which is the main governing parameter of elements mobility upon the formation of Ni laterite deposits (Domènech et al., 2017; Myagkiy et al., 2017). Compared 
to the results of 1-D reactive transport model, which accounts only for vertical downward propagation of $\mathrm{pH}$ dissolution front, one can notice that the migration of the $\mathrm{pH}$ in 2-D domain is in contrast tightly shaped by the topographic gradients. Indeed, the result of present study indicates the downslope progression of oxidizing fluid system, which propagates deeper into the formation with time (Figures 5a and 5b). Such a topography-driven dissolution front movement is accordingly forcing the leaching and remobilization of Ni-bearing minerals, previously accumulated in the upper part. The exportation of the soluble elements $(\mathrm{Ni}$, $\mathrm{Mg}$, and $\mathrm{Si}$ ) in this way should appear from the right to the left part of the profile, in a direction of flow convergence.

The lateral movement of $\mathrm{Ni}$ in aqueous solution is shown in Figures $5 \mathrm{c}$ and $5 \mathrm{~d}$. It can be noticed that the most intense weathering appeared upslope of the saprolitic horizon. The latter led to the progressive dissolution of Ni-bearing minerals, namely, pimelite, due to the migration of $\mathrm{pH}$ front, and subsequent release of nickel to the pore water where it is further transported toward a low relief zone to reach favorable conditions for reprecipitation. As a consequence of this process, the downward movement of the Ni plume with time displayed in Figures $5 \mathrm{c}$ and 5d would result in a constant depletion in nickel concentration within the upper part situated under the lateritic cover. In contrast, transport of Ni with downward moving solution suggests the future formation of most Ni concentrated zones in topographic lows. This downward leaching of the components deeper into the saprolitic formation would also lead to faster development of residual laterites in the upslope zone. It should be noted that compared to the amount of nickel contained in $\mathrm{Mg}$-Ni silicates the total nickel content in relics of olivine within the saprolitic layer was relatively small, so the Ni release into pore water appeared mostly due to pimelite dissolution.

Such a lateral redistribution of the components that appears due to the successive dissolution-precipitation cycles of the secondary minerals underlines its complete difference with classic vertical per descensum model. Indeed, the classically accepted vertical representation for the development of lateritic profile implies the formation and further development of Ni-silicate zones directly under the lateritic cover (Figure 2a). In this case it would suggest that the most Ni concentrated locations should form straight under the thickest laterite. In contrast, the 2-D mineralization model proposed in this work brings out topographic impact and defines that the development of saprolitic zone and the highest Ni enrichment is shifted from the position of the main lateritic body toward the topographic low. The latter is coherent with observations summarized in Golightly (2010) and Quesnel et al. (2017).

Indeed, in a longer simulation time, extended to 500 years, a significant rise of Ni content in a zone of low relief can be observed (Figure 5e). Highest Ni concentrations appear mostly along the slope surface and peak in the lowest topographic part. Moreover, one can see an additional increase of Ni content corresponding to an increase of olivine weathering within the bedrock horizon, in a direction from right to left away from topographic maximum (Figure 5f). The latter phenomenon is explained by the flow convergence. The fluid's maximum speed and circulation in this part has a direct control on the rate of weathering and leads to the most pronounced development of secondary minerals, in particular pimelite toward the topographic low (Figure 5f).

It is worth noting the minor impact of the lateritic cover, observed in the simulations during the formation of Ni high-grade deposit. Surprisingly, it was established that only $0.02 \%$ of Ni deposits reconcentrated in topographic minimum during the remobilization process was related to the dissolution of goethite in the lateritic cover. Indeed, remobilization of nickel was found to be mostly occuring due to (i) redissolution of secondary Ni-bearing silicates in the saprolite zone (about 60\%), and (ii) dissolution of partly preserved in this zone olivine (around 40\%). In contrast with the conceptual model of Butt and Cluzel (2013; Figure 2a), we observe that most of the material responsible for Ni redeposition comes directly from the saprolitic horizon. In addition to the current modeling case, where $\mathrm{pH}$ of entering solution was close to meteoric waters, that is, 6, a higher $\mathrm{pH}$ value of 9 was tested at the right boundary (Figure 5a). It was noticed that the value of $0.02 \%$ of nickel flux incoming from goethite increases approximately by factor 2 in such a case but still has a minor effect in nickel reconcentration process.

The lateral redistribution of nickel may at least partially explain the geometry of the laterite nickel deposits. Indeed, the simulation suggests that the fastest formation of laterite occurs on topographic highs with subsequent development of saprolitic zone in a downslope direction. Such an observation is coherent with recent 3-D geometrical modeling of lateritic covers along with the analyses of core samples at Koniambo massif (Quesnel et al., 2017). Furthermore, the latter observations additionally proved that most of the Ni-rich zones 
form usually where laterite is thin or absent, while the areas with lowest $\mathrm{Ni}$ are located in topographic highs under the thickest lateritic cover. It was additionally proposed by Quesnel et al. (2017) that this process of nickel redistribution may have been enhanced by mechanical transport of laterite materials on the slopes.

The lack of Ni-grade distribution maps for such uplifted profiles complicates the direct comparison of modeling data with in situ observations. Nonetheless, the results of simulations support the new conceptual model of nickeliferous laterites formation through the consistent lateral transfers of nickel, first proposed by Quesnel et al. (2017), and demonstrate that hydraulic gradient controls the migration of dissolution front within the saprolitic layer. Moreover, the model developed determines the formation of Ni enriched hot spots within the topographic low: (i) in the saprolite, due to the lateral progression and reconcentration of nickel and (ii) in the bedrock due to the flow convergence and velocity increase enhancing the fluid-rock interactions. The least $\mathrm{Ni}$ concentrated regions are then developing in the zones of topographic highs regarding the downslope loss of nickel. It should be noted that there were no significant changes recorded in the amount of precipitated Ni-bearing phases within the slope range of $20^{\circ}$ to $30^{\circ}$, common for New Caledonia. Thus, to conclude the topographic features take an important part of mineralization model as they (i) govern and shape the dissolution front propagation, (ii) control the directions of $\mathrm{Ni}$ redistribution, and (iii) guide $\mathrm{Ni}$ exploration.

\subsection{Impact of Fractures On Redistribution of Ore Deposits}

The richest Ni silicate ore in New Caledonian Ni deposits occur in centimeter-thick fractures within the bedrock and saprolite, located several tens of meters to hundred meters below the present-day surface. Compared with saprolite that contains only $2-5 \mathrm{wt} \% \mathrm{Ni}$, garnierite veins may grade up to $25-40 \mathrm{wt} \% \mathrm{Ni}$. The development of fracture sets enhances the infiltration and mobility of superficial waters and makes room for new material to crystallize. The mineralization of preferential pathways as well as its impact on remobilization of nickel from upper layers will be discussed in this section. For the sake of simplicity and for illustrative purposes, only a single fracture will be considered and impact of fractures network connectivity will be discarded.

In the simulation case that takes into account the fracture presence an additional refinement was required along the fractures. Therefore, a study of mesh convergence was performed in order to check is there any dependency of the results on different mesh sizes. Based on the convergence study, a triangular mesh with 2,712 nodes was chosen, which conducts correct convergence of the simulations.

Figures $6 \mathrm{a}$ and $6 \mathrm{~b}$ display the redistribution of initially uniformly spread Ni-silicate within the saprolite zone after 50 and 100 years. Flow vectors (arrows) show the influence of fracture presence on local hydrodynamic system in terms of Darcy velocity field. The fracture impact is distinctly marked by the divergence of the flow into two primary components. The first one moves the chemically active fluid with dissolved remobilized $\mathrm{Ni}, \mathrm{Si}$, and $\mathrm{Mg}$ toward the preferential pathway. As a result, it leads to an increase of Ni concentration in the vicinity of a fracture at the saprolite-bedrock interface (Figure 6b). Eventually, as the flow converges in this zone the solutes propagate inward the fracture through successive dissolution-precipitation cycles. The second component of the flow accordingly moves the solution in the direction of topographic low, downslope where the subsequent increase of Ni content occurs. Such a formation of Ni mineralization hot spot was discussed in the previous section case. It should only be noted that the redistribution in between the flow components (and transport) depends on the position of the fracture, its length, and the location of aquifer discharge defined by the value of hydraulic head at the fracture tip. Thus, lower the discharge than more passive will be the preferential pathway impact on hydrodynamics. Nevertheless, the phenomenon stays the same leading to both formation of deposits (i) in low relief zone and (ii) within the fractures.

The occurrence of relatively large amounts of nickel silicate in veins makes the investigation of fracture-controlled tectonic drainage an important part of Ni mineralization model. In order to find out how these deposits develop, let us turn to geochemical modeling outputs. The presence of the crack would result in the increase of water infiltration and mobility of circulating fluids within and in the vicinity of the preferential pathway. The latter respectively leads to a significant rise of the weathering rate in the bedrock zone and results in a progressive dissolution of primary rock, that is, olivine. Indeed, as one can see from Figure $6 \mathrm{~d}$ olivine mostly dissolves along the fracture path with the highest rate of dissolution at the place where the fluid enters the fracture. Subsequently, it results in a formation of secondary weathering product, pimelite, which formation after 100 years of simulated time is demonstrated in Figure 6c. Therefore, 

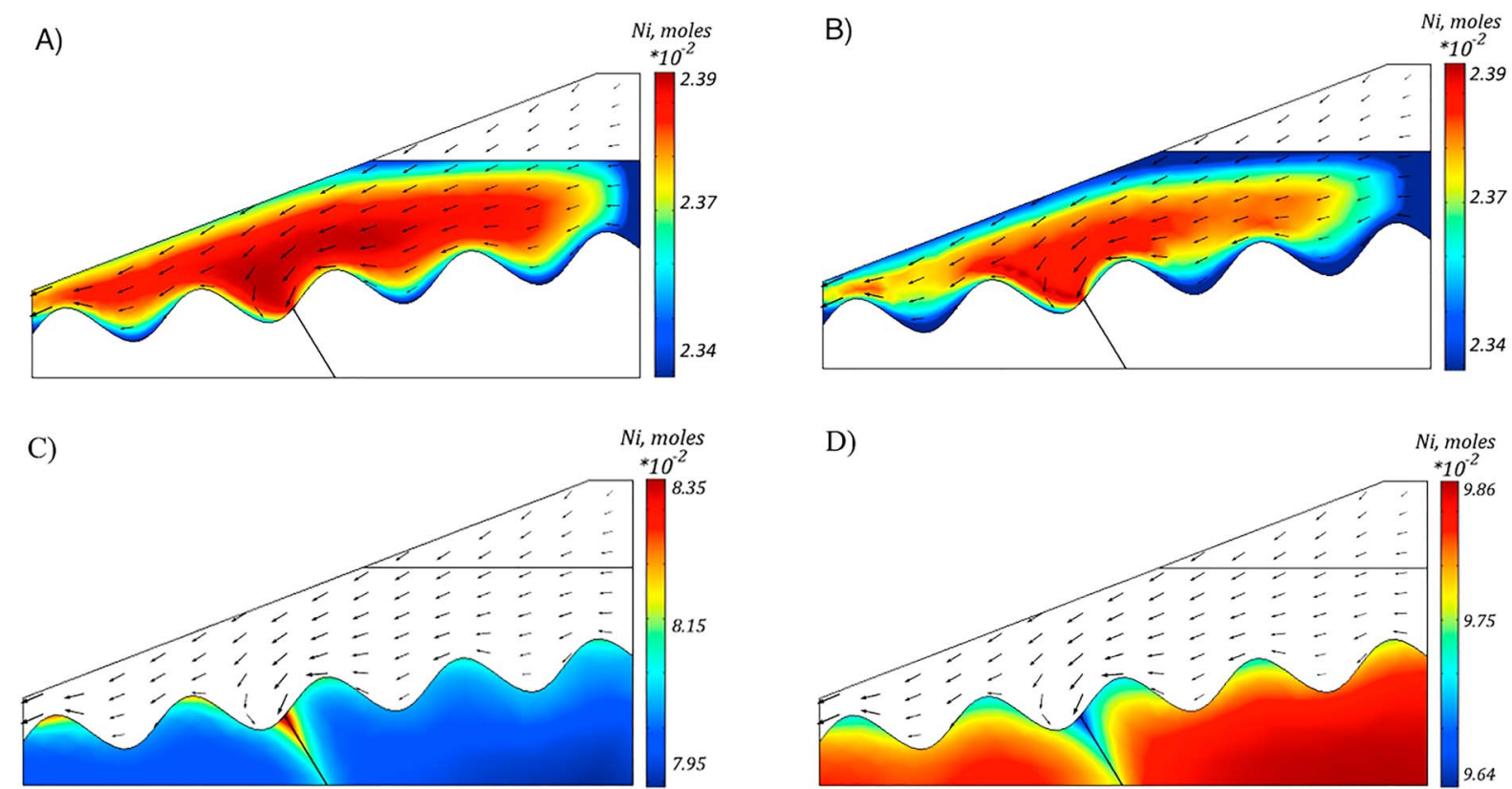

Figure 6. Evolution of total Ni content in solid phase within the saprolite zone after (a) 50 years and (b) 100 years. (c) Ni content in pimelite after its precipitation in the bedrock zone and in the vicinity of the fracture after 100 years, and (d) Ni content in olivine due to its dissolution within the bedrock zone after 100 years.

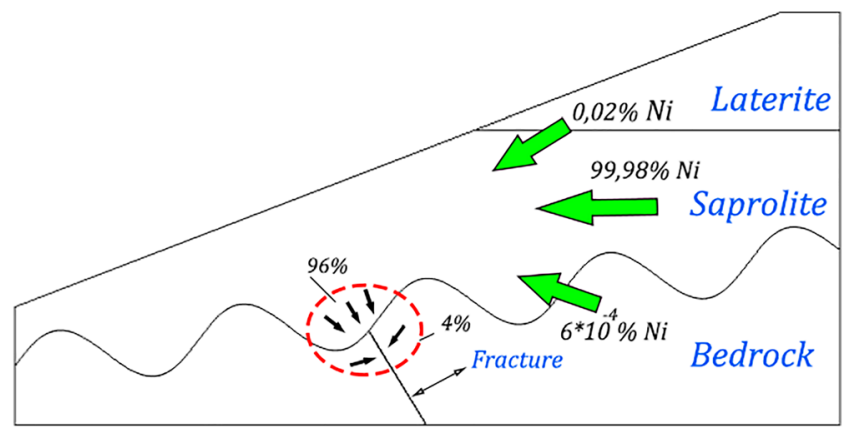

Figure 7. Comparison of fluxes with dissolved Ni that come from different geological layers. the increase in the fluid velocity toward the fracture has a direct impact on the dissolution processes and consequent formation of $\mathrm{Ni}$ deposits.

The incoming fluxes with dissolved Ni entering from different horizons were calculated and compared in order to define the contribution of each geological layer into the formation of nickel ore deposits. Such a flux with nickel dissolved that enters from laterite and bedrock geological layers was calculated through their interface with saprolitic horizon. At the same time, the flux within the saprolitic zone was directly calculated from the values of dissolution of Ni-bearing phases within this region. The results of calculation revealed that $99.98 \%$ of $\mathrm{Ni}$ that found to be reprecipitated in the low relief zone (e.g., Figures 5e and 6b) was formed due to the dissolution of olivine and secondary Ni-bearing mineral phases in the saprolite zone, while only $0.02 \%$ and $6 \times 10^{-4} \%$ of nickel were related to contribution of laterite and bedrock horizons respectively (Figure 7). To investigate further the input of the bedrock into the formation of deposits in fractures, we compare the flux of dissolved nickel at the entrance of the fracture that comes from saprolite horizon, with the flux of Ni dissolved in the bedrock zone and flowing to the fracture from the interface (fracture walls). Such a comparison at the fracture scale shows that the income of Ni to the inside of the crack from the bedrock represents around $4 \%$ out of total nickel source, while $96 \%$ of Ni comes from the saprolite horizon (Figure 7). A denser fracture's network would lead to a drastic increase of the reactive surface area and, therefore, further enhance the contribution of the bedrock dissolution to the formation of fractures infillings.

Additional cross sections through the fracture may give an insight into the volumes and distribution of $\mathrm{Ni}$ ore within that zone. As discussed above, the entrance of fluid in the crack leads to the transport of soluble components, in particular Ni, from the upper saprolite horizon (Figure 7) which results in subsequent oversaturation with respect to pimelite (Figure 8). The effect is enhanced by the dissolution processes that occur on fracture walls presented by olivine material. The impact of fracture presence on a fluid velocity field and weathering rates is discussed above and may lead to the additional enrichment in Ni through the advective/diffusive solute transport from bedrock inward the crack. As a result we can observe precipitation of pimelite all along the fracture as displayed in Figure 8. In spite of that, one can note a dramatic decrease in volumes of precipitated material along the fracture's length. Indeed, most of the pimelite 


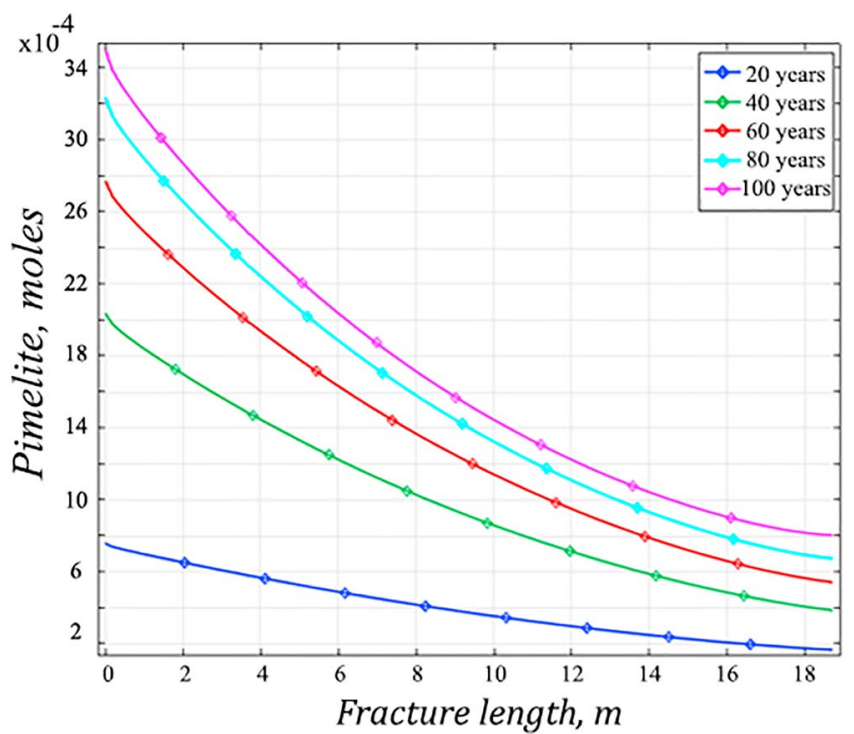

Figure 8. Precipitation of pimelite within the fracture. Data are presented along the fracture length with time. precipitation occurs at the very onset of the crack, especially in its first few meters. Then, the amount of precipitated pimelite is gradually and nonlinearly reducing, while the difference in precipitation amounts between the inlet of the fracture and its tip is further noted to grow with time (Figure 8). Such a phenomenon is caused by the depletion of the dissolved mineralizing components of the fluid at the entrance of the fracture and further enhanced by more intense dissolution of olivine at the upper fracture part (Figure 6d). Here again, the balance between precipitation rate at the inlet and solute transport inward the fracture is strongly driven by the value of hydraulic head at the fracture tip, and more uniform precipitation patterns could be observed depending on the flow rate conditions.

Most cracks in New Caledonia are filled with Ni-Mg kerolite only (modeled as pimelite, Table 3), have homogeneous green color, rich in nickel, and most probably have been formed during one single episode of supergene enrichment (Cluzel \& Vigier, 2008). Nevertheless, a recent study of sets of fractures sealed with Ni-rich silicates and quartz, which generally occur within the fractured bedrock zone of the New Caledonian regolith, revealed a more complex enrichment process through their multiple stage formation. It was inferred that most of the veins represented by $\mathrm{Ni}-\mathrm{Mg}$ kerolite accompanied by quartz-hematite material correspond to the stages of cracking and sealing events that take place in preexisting fractures (Cathelineau, Myagkiy, et al., 2016). The order of time needed to seal a reopened fracture with pimelite can be estimated in accordance with following expression:

$$
\left\{\begin{array}{c}
\phi=1-\phi_{\text {inert }}-\sum_{i}^{N_{m}} V_{m, i} c_{m, i}, \\
\tau=f^{-1}\left(c_{m, i}\right)
\end{array}\right.
$$

where $\phi$ stands for porosity within the fracture, $\phi_{\text {inert }}$ denotes the volume fraction of nonreactive minerals, set to 0 as we assume sealing only with pimelite, $V_{m}$ is the molar volume of the reactive mineral $(\mathrm{L} / \mathrm{mol})$, $c_{m}$ is the mineral concentration that should be expressed in moles of mineral per volume of porous medium (mol/L), and $\tau$ is a time of mineral precipitation.

Once $\phi$ becomes equal to 0 , the fracture is considered to be completely clogged. Thus, linear extrapolation of the simulation results related to precipitation within the fracture (Figure 8) yields its estimated entire clogging over around 150,000 years during the Ni stage (i.e., pimelite formation), assuming the density of pimelite as $2.75 \mathrm{~g} / \mathrm{cm}^{3}$ and, thus, its molar volume $\left(V_{m}=M / \rho\right)$ as $0.19 \mathrm{~L} / \mathrm{mol}$. After, the fracture is meant to be mechanically reopened again which leads to a new stage of mineral precipitations in it, as discussed in Cathelineau, Myagkiy, et al. (2016). It is worth noting that this calculation represents a very first estimate of time needed to seal the fracture since in real systems the permeability of fracture and hence the flux rate through it are expected to reduce progressively with time due to pimelite precipitation.

To summarize, the occurrence of supergene nickel ore in fractures is a consequence of (i) nickel-bearing fluid migration through a fractured rock with dissolved mineralizing components from saprolite horizon, (ii) dissolution of bedrock reinforced by the presence of crack that leads to more intense weathering in its vicinity zone, and (iii) precipitation of pimelite within the fracture. Moreover, the modeling results did not reveal any noticeable chemical dissolutions in goethite-rich lateritic horizon thus making a conclusion that its contribution in remobilized $\mathrm{Ni}$ enrichment is minor. The latter is in opposite to unidimensional concept proposed by Butt and Cluzel (2013), which suggested reactivation of Ni from the oxide zone of uplifted formation due to redissolution of Ni-bearing goethite and its following accumulation in hydrous $\mathrm{Mg}-\mathrm{Ni}$ silicates deeper in the saprolite zone. It is worth noting, however, that a part of Ni could be expelled from oxides due to the goethite recrystallization during its aging process (Dublet et al., 2015), which cannot be estimated as has not been modeled here.

\subsection{Weathering of Peridotite Corestone Within the Set of Fractures. Target-Like Ore}

The final model presented in this work is an investigation of the impact of fracture networks on weathering processes and mineralizations, that occur within the bedrock horizon. More interestingly, this model can 

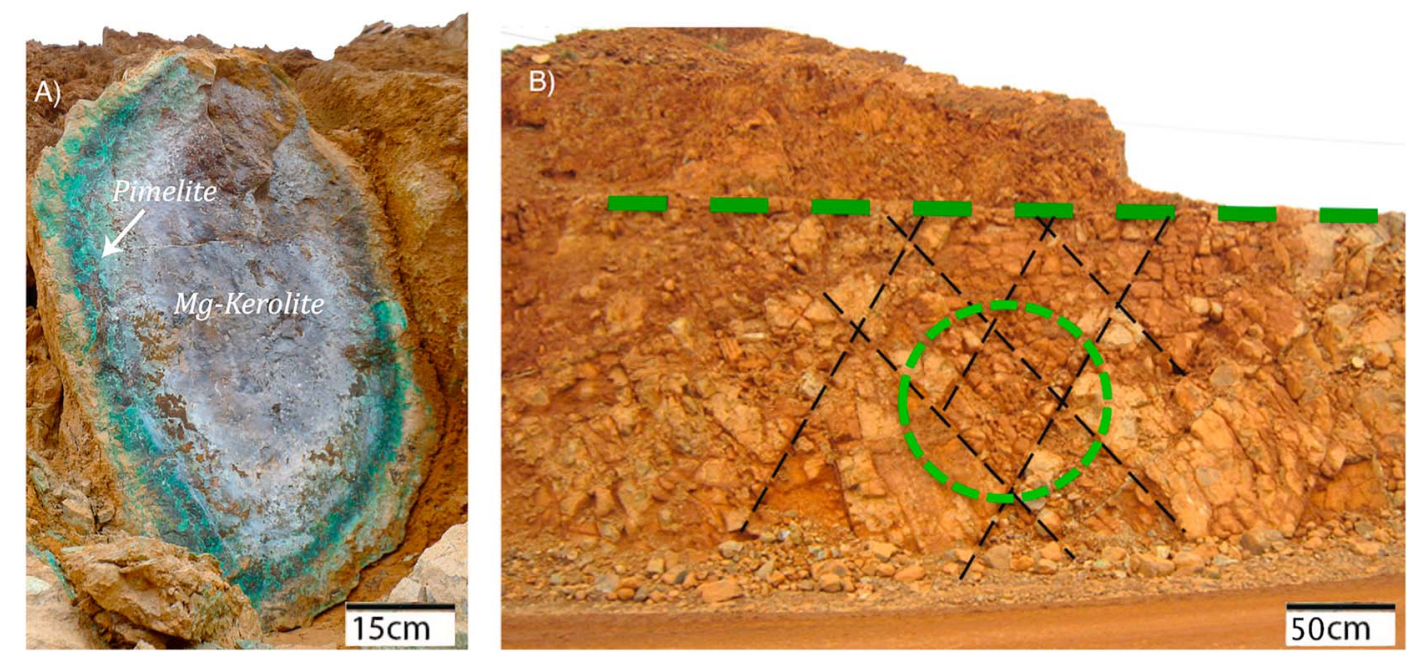

Figure 9. (a) Field occurrences of target-like ores and (b) representation of regular fractures network delineating blocks or boulders within the bedrock.

easily explain the problem of silicate precipitation process in New Caledonia, namely, zonation in silicates. First discriminated by Cathelineau, Quesnel, et al. (2016), similar to a shooting target and that is why it is called "target-like" (Figure 9a), this mineralization is characterized by concentric mineralogical zoning that consists of (from the edge to the center): (i) a highly oxidized and altered zone, (ii) a green Ni-rich pimelite zone, (iii) a zone (limited to a few centimeters) with a mixture of Ni-poor kerolite and Ni-rich pimelite, and (iv) a large white Mg-kerolite mineralization zone. Current genetic model of this concentric type of ore proposes the oversaturation of the solution, with respect to silicate due to the water evaporation which occurs when the water table level is low. In this way, increased activities of $\mathrm{Ni}, \mathrm{Mg}$, and $\mathrm{Si}$ in solution may lead to pimelite and kerolite precipitation. In the present work, we propose an alternative formation model of target-like ore based on direct supergene weathering of blocks under fully saturated conditions.

Representative element of regular fractures network used to simulate the formation of boulders is displayed in Figure 9b. The rocky blocks are found within the first hundred meters below the surface and closely associated with the mineralized fractures with pimelite infilling discussed in the previous section. The extension of the blocks ranges from a few decimeters to $1 \mathrm{~m}$. Initially, the modeled system represents a fully satu-
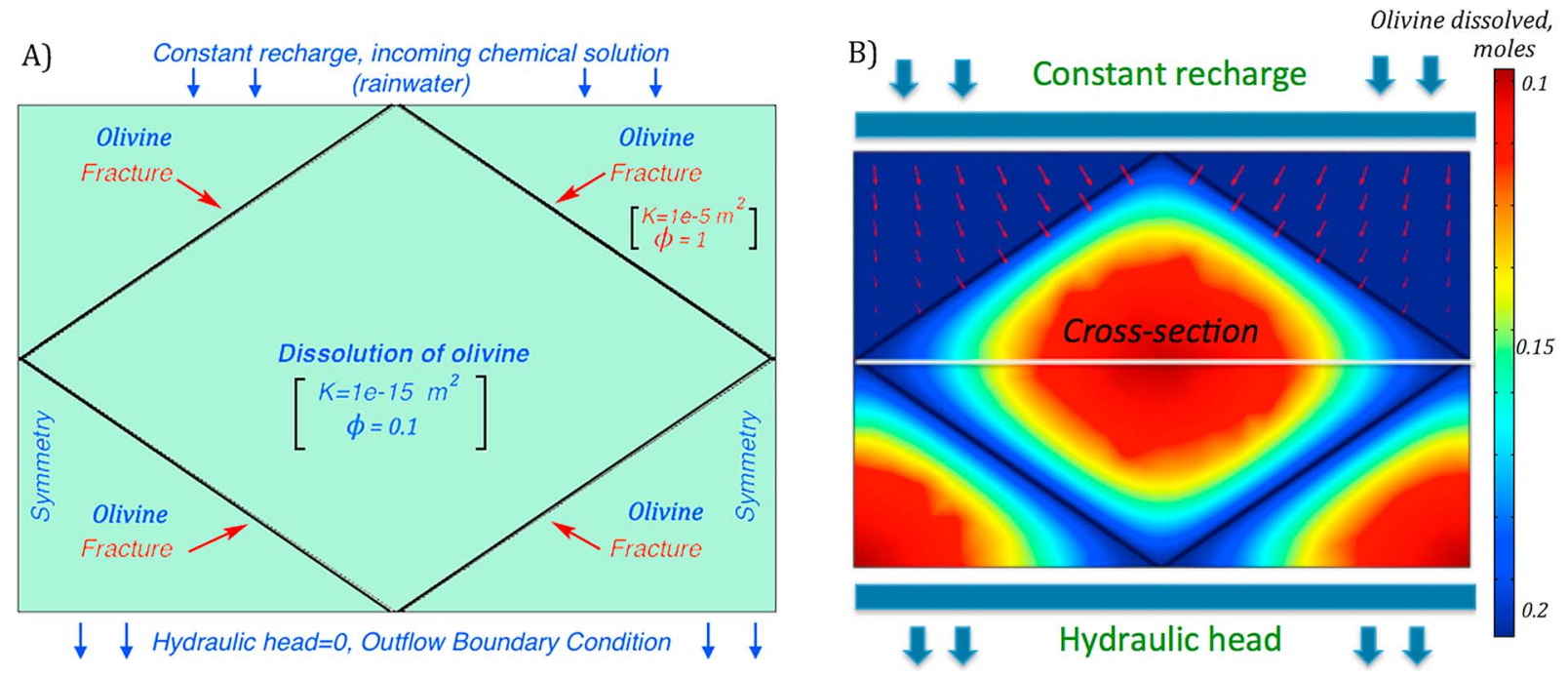

Figure 10. (a) Boundary conditions of the modeled representative element, dimensions $2 \times 3 \mathrm{~m} . K$ and $\phi$ stand for permeability and porosity within the rock (values are indicated in blue) and the fractures zone (values are indicated in red). (b) Weathering of peridotite corestone within the fracture network: olivine dissolved, in moles, after 30 years. Red arrows represent the velocity fields. A cross section of this boulder structure, depicted above by a gray line, is shown in Figure 11 . 

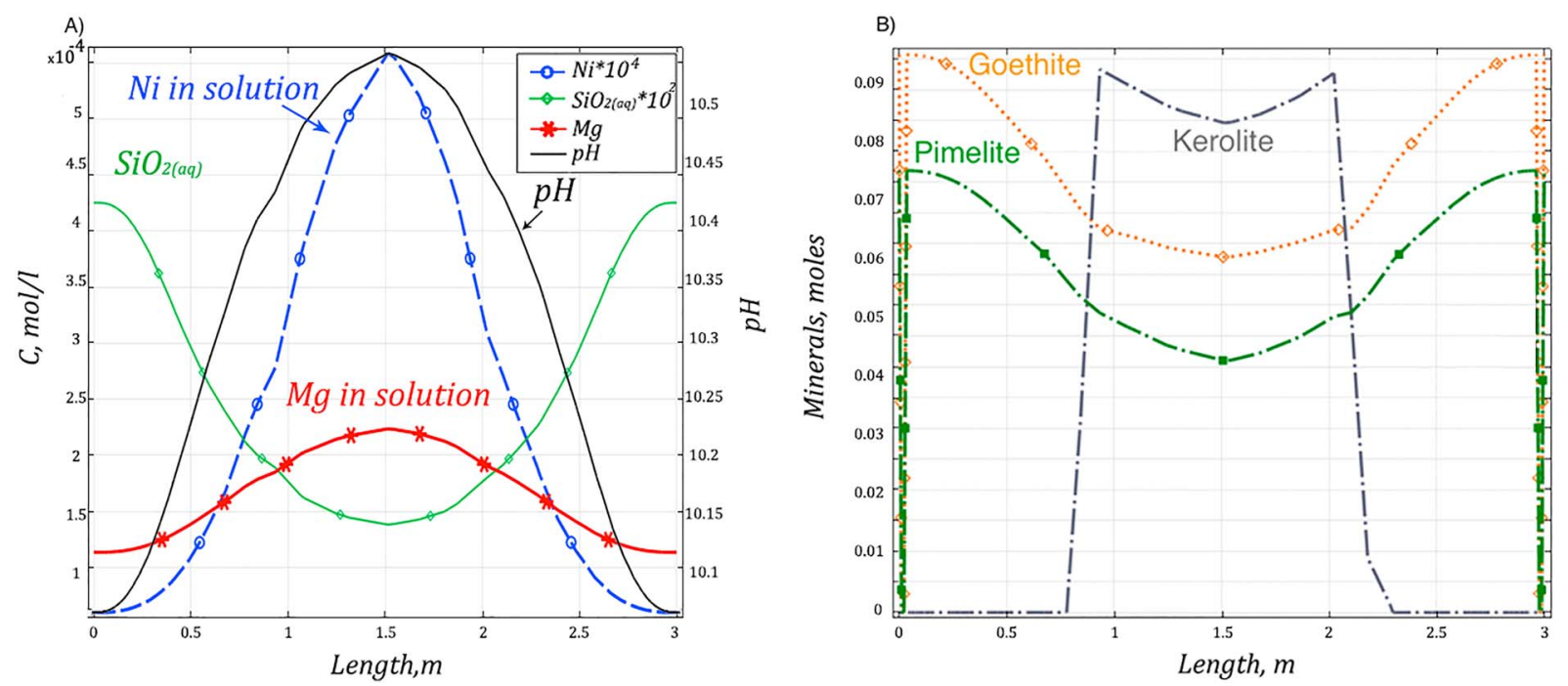

Figure 11. (a) $\mathrm{pH}$ values and chemical composition of the fluid along a boulder cross section after 30 years. (b) Secondary mineral precipitations along a boulder cross section after 30 years.

rated domain. It contains pure bedrock represented by olivine and four cracks delineating the weathering block. The reactions involved in simulations along with minerals allowed for precipitation and dissolution are listed in Table 3. The imposed boundary conditions are presented in detail in Figure 10a.

In Figure 10b, one can observe the result of a dissolution of the primary material in a block within the set of fractures and subsequent boulder formation. After 30 years, around $2 \%$ of olivine was dissolved resulting in precipitation of goethite, pimelite and kerolite. The impact of the crack system is direct, as it promotes fluid circulation and weathering of the delineated boulder. Mineralization occurs toward the center of the blocks with most intense weathering around the rim. Simulated paragenesis along a boulder cross section (Figure 11b) reproduces perfectly the formation of concentric zonation of goethite and $\mathrm{Ni}-\mathrm{Mg}$ silicates by taking into account (i) the respective solubility product of pimelite and kerolite, (ii) the geometry of the fracture network, and (iii) the solution flow along the fractures.

The precipitation sequence is explained by the $\mathrm{pH}$ dependence of the solubility of the minerals. As it is displayed in Figure 11, lower $\mathrm{pH}$ values of the fluid entering from the edges of the block result in the formation of oxides (goethite) rim, which is followed by precipitation of Ni-Mg silicates, from less soluble pimelite to more soluble kerolite. The sequence is controlled by thermodynamic constants that are listed in Table 3.

Concentration of $\mathrm{Ni}$ dissolved in solution has a shape which is similar to $\mathrm{pH}$ distribution along a boulder cross section (Figure 11a). Indeed, being released by the dissolution of olivine, nickel attains its maximum dissolved concentration at the center of the block with minimum values at the edges. The latter is caused by the largest precipitation of pimelite at the external layer of the boulder (Figure 11b) that prevails over the dissolution of olivine. On the contrary, aqueous silica concentration in solution is dramatically decreasing toward the center of the block. Such an effect is enhanced by simultaneous precipitation of both pimelite and kerolite in the vicinity of block center that leads to the minimum concentration of silica in this area. Finally, $\mathrm{Mg}$ concentration should be in accordance with precipitation of kerolite (Figure 11b) and, thus, is expected to decrease toward the center, where the largest precipitation of the kerolite takes place. However, the reverse behavior is observed. Indeed, one can notice an apparent increase in concentration of magnesium from $1.12 \times 10^{-4}$ up to $2.2 \times 10^{-4} \mathrm{~mol} / \mathrm{L}$ when approaching the center of the block (Figure 11a). The latter may be explained by relatively low concentration of magnesium contained in incoming meteoric water solution $4.1 \times 10^{-5} \mathrm{~mol} / \mathrm{L}$ (see Myagkiy et al., 2017, Figure 3) that penetrates from the fractures into the delineated boulder. Subsequent mixing of infiltrating fluid with a pore water in the boulder therefore results in observed decrease in $\mathrm{Mg}$ concentration in the vicinity of the block rim. 


\section{Conclusions}

Presented mineralization model provides a new concept of ore genesis that explains metal enrichment in saprolites as well as within the fractured bedrock zone, taking into account preferential pathways, lateral movement, and topographic influence during the supergene alteration processes. In contrast to metallogenic models developed for New Caledonian deposits, namely, per descensum formation with vertical downward leaching of mineralizing components, it highlights a critical control of geological structures on Ni ore development. This renewed examination based on a hydrodynamic and geochemical study allowed to provide a numerical explanation of the distinguished in situ main Ni-enriched hot spots observed in the profiles of New Caledonia. First, the simulations suggest that the lateral progression of the $\mathrm{pH}$ front in uplifted profiles is tightly shaped by geometry of weathering zones and its propagation deeper in the saprolite leads to a faster development of lateritic horizon upslope with subsequent leaching of soluble components, in particular Ni in a downslope direction. The latter results in increase of the nickel content of the saprolite located in the slope zones and topographic lows which further supports the concept of lateral Ni migration proposed by Quesnel et al. (2017) based on the drill core data set coupled with 3-D geometrical model of nickel laterite ore deposit. Second, the modeling revealed a direct impact of the presence of preferential pathways (fractures) within the bedrock on redistribution of the flow and, thus, on transport of mineralizing components with subsequent enrichment within the fractures. The phenomenon was additionally found to be enhanced by the dissolution processes that occur in the vicinity of fracture and lead to the entrance of dissolved elements inward the fracture from the bedrock zone. Third, the modeling of a system reproducing the boulders alteration demonstrated direct impact of the fractures network on the weathering and mineralization processes within the delineated block. Moreover, the results of the mineral paragenesis within the boulder were coherent with nature observations and allowed to propose a new model of concentric ore formation in a fully saturated media.

To sum up, mineralizing processes including remobilization, chemical solution drainage, and ore formation are strongly linked with the hydrodynamics of studied profiles. The present-day distribution of minerals within the regolith of New Caledonia appears thus as the result of complex superimposed chemically and structurally controlled processes acting simultaneously and shaping the Ni ore deposits to its current form. The developed conceptual model is certainly simpler than the real flow system in the profiles but captures the important overall features of the real system. Thus, the presented model further can be extended to a simulation of specific geological structures at the deposit scale and may be of great help in mineral prospecting and forecasting the distribution of future resources by mining companies.

\section{References}

This work has been supported by the French National Research Agency through the national program "Investissements d'avenir" with the reference ANR-10-LABX-21-01/LABEX RESSOURCES21. The geochemical data used in this study and thermodynamic database of the model are included in the supporting information.
Aghbelagh, Y. B., \& Yang, J. (2017). Role of hydrodynamic factors in controlling the formation and location of unconformity-related uranium deposits: Insights from reactive-flow modeling. Hydrogeology Journal, 25(2), 465-486.

Barry, D. A., Miller, C. T., \& Culligan-Hensley, P. J. (1996). Temporal discretisation errors in non-iterative split-operator approaches to solving chemical reaction/groundwater transport models. Journal of Contaminant Hydrology, 22(1-2), 1-17.

Butt, C. R. M., \& Cluzel, D. (2013). Nickel laterite ore deposits: Weathered serpentinites. Elements, 9, 123-128.

Carrayrou, J., Mosé, R., \& Behra, P. (2004). Operator-splitting procedures for reactive transport and comparison of mass balance errors. Journal of Contaminant Hydrology, 68(3), 239-268.

Cathelineau, M., Myagkiy, A., Quesnel, B., Boiron, M. C., Gautier, P., Boulvais, P., et al. (2016). Multistage crack seal vein and hydrothermal Ni enrichment in serpentinized ultramafic rocks (Koniambo Massif, New Caledonia). Mineralium Deposita, 52(7), 945-960.

Cathelineau, M., Quesnel, B., Gautier, P., Boulvais, P., Couteau, C., \& Drouillet, M. (2016). Nickel dispersion and enrichment at the bottom of the regolith: Formation of pimelite target-like ores in rock block joints (Koniambo Ni deposit, New Caledonia). Mineralium Deposita, 51(2), 271-282.

Chevillotte, V., Chardon, D., Beauvais, A., Maurizot, P., \& Colin, F. (2006). Long-term tropical morphogenesis of New Caledonia (southwest Pacific): Importance of positive epeirogeny and climate change. Geomorphology, 81(3), 361-375.

Cluzel, D., \& Vigier, B. (2008). Syntectonic mobility of supergene nickel ores of New Caledonia (southwest Pacific). Evidence from garnierite veins and faulted regolith. Resource Geology, 58(2), 161-170.

Domènech, C., Galí, S., Villanova-de Benavent, C., Soler, J. M., \& Proenza, J. A. (2017). Reactive transport model of the formation of oxide-type Ni-laterite profiles (Punta Gorda, Moa Bay, Cuba). Mineralium Deposita, 52(7), 993-1010.

Dublet, G., Juillot, F., Morin, G., Fritsch, E., Fandeur, D., \& Brown, J. G. (2015). Goethite aging explains Ni depletion in upper units of ultramafic lateritic ores from New Caledonia. Geochimica et Cosmochimica Acta, 160, 1-15.

Dzombak, D. A., \& Morel, F. M. M. (1990). Surface complexation modeling: Hydrous ferric oxide. New York: John Wiley.

Fridleifsson, I. B., Bertani, R., Huenges, E., Lund, J. W., Ragnarsson, A., \& Rybach, L. (2008). The possible role and contribution of geothermal energy to the mitigation of climate change. In IPCC Scoping Meeting on Renewable Energy Sources, Proceedings (Vol. 20, pp. 59-80). Luebeck, Germany: Intergovernmental Panel on Climate Change.

Golightly, J. (1979). Geology of Soroako nickeliferous laterite deposits. In AIME International Laterite Symposium (pp. 38-55). New Orleans. Golightly, J. P. (1981). Nickeliferous laterite deposits. In Economic Geology, 75th anniversary volume (pp. 710-735). 
Golightly, J. P. (2010). Progress in understanding the evolution of nickel laterites. Society of Economic Geologists Special Publication, 15, 451-485.

Hobbs, B. E., Zhang, Y., Ord, A., \& Zhao, C. (2000). Application of coupled deformation, fluid flow, thermal and chemical modelling to predictive mineral exploration. Journal of Geochemical Exploration, 69, 505-509.

Jacques, D., Simunek, J., Mallants, D., \& Van Genuchten, M. T. (2006). Operator-splitting errors in coupled reactive transport codes for transient variably saturated flow and contaminant transport in layered soil profiles. Journal of Contaminant Hydrology, 88(3), 197-218.

Jeanpert, J., \& Dewandel, B. (2013). Analyse préliminaire des donées hydrogéologiques du massif du Koniambo. Public Report BRGM/RP-61765-FR

Johnson, J., Anderson, G., \& Parkhurst, D. (2000). Database from thermo.com.v8.r6.230 prepared at Lawrence Livermore National Laboratory. (Revision: 1.11).

Join, J. L., Robineau, B., Ambrosi, J. P., Costis, C., \& Colin, F. (2005). Système hydrogéologique d'un massif minier ultrabasique de Nouvelle-Calédonie. Comptes Rendus Geoscience, 337(16), 1500-1508.

Latham, M. (1986). Altération et pédogenèse sur roches ultrabasiques en Nouvelle-Calédonie: Genèse et évolution des accumulations de fer et de silice en relation avec la formation du modelé. IRD Editions ( $\mathrm{PhD}$ thesis), University of Dijon.

Leguere, J. (1976). Des corrélations entre la tectonique cassante et l'altération supergène des péridotites de Nouvelle Calédonie (PhD thesis), University of Montpellier.

Murphy, M., Parker, H., Ross, A., \& Audet, M.-A. (2004). Ore-thickness and nickel grade resource confidence at the Koniambo nickel laterite (a conditional simulation voyage of discovery), Geostatistics Banff 2004 (pp. 469-478). Dordrecht: Springer.

Myagkiy, A., Truche, L., Cathelineau, M., \& Golfier, F. (2017). Revealing the conditions of Ni mineralization in the laterite profiles of New Caledonia: Insights from reactive geochemical transport modelling. Chemical Geology, 466, 274-284.

Nardi, A., Idiart, A., Trinchero, P., de Vries, L. M., \& Molinero, J. (2014). Interface COMSOL-PHREEQC (iCP), an efficient numerical framework for the solution of coupled multiphysics and geochemistry. Computers \& Geosciences, 69, 10-21.

Nriagu, J. O. (1975). Thermochemical approximation for clay minerals. American Mineralogist, 60, 834-839.

Parkhurst, D. L., \& Appelo, C. A. J. (2013). Description of input and examples for PHREEQC version 3-A computer program for speciation, batch-reaction, one-dimensional transport, and inverse geochemical calculations, U.S. Geological Survey Techniques and Methods, book 6, $A 43$ (pp. 497). Reston, VA: U.S. Department of the Interior. Retrieved from http://pubs.usgs.gov/tm/06/a43/

Pelletier, B. (1996). Serpentine in nickel silicate ore from New Caledonia (pp. 197-205). Carlton South: Nickel'96: Mineral to market. Pelletier, B. (2003). Les minerais de nickel de Nouvelle-Calédonie. GEOLOGUES-PARIS.

Pokrovsky, O. S., \& Schott, J. (2000). Kinetics and mechanism of forsterite dissolution at $25^{\circ} \mathrm{C}$ and pH from 1 to 12 . Geochimica et Cosmochimica Acta, 64, 3313-3325.

Prigiobbe, V., Hänchen, M., Costa, G., Baciocchi, R., \& Mazzotti, M. (2009). Analysis of the effect of temperature, $\mathrm{pH}^{\mathrm{C}} \mathrm{CO}_{2}$ pressure and salinity on the olivine dissolution kinetics. Energy Procedia, 1(1), 4881-4884.

Quesnel, B., de Veslud, C. L. C., Boulvais, P., Gautier, P., Cathelineau, M., \& Drouillet, M. (2017). 3D modeling of the laterites on top of the Koniambo Massif, New Caledonia: Refinement of the per descensum lateritic model for nickel mineralization. Mineralium Deposita, 52(7), 961-978.

Saaltink, M. W., Carrera, J., \& Ayora, C. (2001). On the behavior of approaches to simulate reactive transport. Journal of Contaminant Hydrology, 48(3), 213-235.

Sevin, B., Ricordel-Prognon, C., Quesnel, F., Cluzel, D., Lesimple, S., \& Maurizot, P. (2012). First palaeomagnetic dating of ferricrete in New Caledonia: New insight on the morphogenesis and palaeoweathering of Grande Terre. Terra Nova, 24(1), 77-85.

Stoessell, R. K. (1988). $25^{\circ} \mathrm{C}$ and $1 \mathrm{~atm}$ dissolution experiments of sepiolite and kerolite. Geochimica et Cosmochimica Acta, 52, 365-374.

Thornber, M. R. (1992). The chemical mobility and transport of elements in the weathering environment. Regolith exploration geochemistry in tropical and subtropical terrains. Handbook of Exploration Geochemistry, 4, 79-96.

Trescases, J. J. (1975). L'évolution géochimique supergène des roches ultrabasiques en zone tropicale: Formation des gisements nickélifères de Nouvelle-Calédonie, Mémoires ORSTOM, 78. Strasbourg: Th. Sci. Nat.: Université Louis Pasteur.

Troly, G., Esterle, M., Pelletier, B., \& Reibel, W. (1979). Nickel deposits in New Caledonia: Some factors influencing their formation (pp. 85-119). New Orleans: International Laterite Symposium.

Ulrich, M. (2010). Péridotites et serpentinites du complexe ophiolitique de la Nouvelle-Calédonie (PhD thesis), Université de la Nouvelle-Calédonie et Université de Grenoble.

Villanova-de-Benavent, C., Proenza, J. A., Galí, S., García-Casco, A., Tauler, E., Lewis, J. F., \& Longo, F. (2014). Garnierites and garnierites: Textures, mineralogy and geochemistry of garnierites in the falcondo Ni-laterite deposit, Dominican Republic. Ore Geology Reviews, 58 91-109.

Zhang, Y., Schaubs, P. M., Zhao, C., Ord, A., Hobbs, B. E., \& Barnicoat, A. C. (2008). Fault-related dilation, permeability enhancement, fluid flow and mineral precipitation patterns: Numerical models. Geological Society, London, Special Publications, 299(1), 239-255. 